\title{
Catalytic hydrodeoxygenation of pyrolysis oil over nickel-based catalysts under $\mathrm{H}_{2} / \mathrm{CO}_{2}$ atmosphere
}

\author{
Wolfgang Olbrich ${ }^{*}$, Chiara Boscagli ${ }^{1}$, Klaus Raffelt ${ }^{1}$, Hao Zang $^{2}$, Nicolaus Dahmen ${ }^{1}$ and Jörg Sauer ${ }^{1}$
}

\begin{abstract}
Background: Renewable feedstocks and bio-refinery concepts are the key to a successful transition to a sustainable chemical industry. One conceivable refinery concept is based on pyrolysis oils from biomass, though these oils are quite difficult to handle. A well investigated approach to upgrade pyrolysis oil and turn it into a valuable products is catalytic hydrodeoxygenation (HDO). However, this process has to be optimized and new ideas are needed to make the hydrodeoxygenation process attractive sustainable and economically competitive. With regard to the many successful applications of gas-expanded liquids in heterogeneous catalysis, the expansion of pyrolysis oil with carbon dioxide was applied in the context of a hydrodeoxygenation reaction. The catalyst used for $\mathrm{HDO}$ was $\mathrm{Ni} / \mathrm{Al}_{2} \mathrm{O}_{3}$ (nickel loading $20 \% \mathrm{wt}$ ).

Results: The influence of $\mathrm{CO}_{2}$ on the viscosity was found to be quite strong at low temperature. At $52^{\circ} \mathrm{C}$ and a $\mathrm{CO}_{2}$ pressure of $0.5 \mathrm{MPa}$ the viscosity is reduced by $30 \%$. With $4.0 \mathrm{MPa}$ of $\mathrm{CO}_{2}$ the viscosity decreases by $60 \%$. With supercritical $\mathrm{CO}_{2}$ a volume expansion of $5 \%$ was observed. The hydrodeoxygenation showed best results at $340{ }^{\circ} \mathrm{C}$ and autogenous pressure. The experiments were started at a total pressure of $8.0 \mathrm{MPa}$ at room temperature $\left(\mathrm{H}_{2}+\mathrm{CO}_{2}\right)$, with a respective partial pressure of $\mathrm{CO}_{2}$ of $0 \mathrm{MPa}, 2.0 \mathrm{MPa}$ or $4.0 \mathrm{MPa}$. A deoxygenation degree of around $70 \%$ could be reached (dry basis) under each atmosphere. The analysis of the upgraded products by different techniques indicated a slight decrease of hydrogenation with increasing the pressure of $\mathrm{CO}_{2}$.

Conclusions: Despite we observed a change in the physical properties when expanding the pyrolysis oil with $\mathrm{CO}_{2}$, no real improvement of the catalytic hydrodeoxygenation reaction (e.g. deoxygenation degree) could be found yet. Possible reasons for the absence of gas-expanded liquid effects could be the polar nature of the used pyrolysis oil and the high temperature. We assume that a viscous and more tar-like, but less polar pyrolysis oil will be more influenced. Gas-expansion with $\mathrm{CO}_{2}$ tends to be less effective with polar liquids due to the unpolar nature of $\mathrm{CO}_{2}$. The only observed effect in our actual system was a decrease of the hydrogenation with decreasing partial pressure of hydrogen.
\end{abstract}

Keywords: Hydrodeoxygenation, Pyrolysis oil, Nickel-based catalyst, Gas-expanded liquid, Carbon dioxide

\section{Background}

Pyrolysis oils from biomass are considered to play a key role in future of biorefineries. Due to their higher-energy density (approx. 15-30 MJ/kg) and chemical composition

\footnotetext{
*Correspondence: wolfgang.olbrich@student.kit.edu

${ }^{1}$ Karlsruhe Institute of Technology, Institute of Catalysis Research and Technology, Hermann-von-Helmholtz-Platz 1, 76344 EggensteinLeopoldshafen, Germany

Full list of author information is available at the end of the article
}

they are an attractive platform feedstock in the bioeconomy [1]. The main problems in use and handling of pyrolysis oils are their high viscosity, high acidity, lower heating value than fossil fuels and low phase stability [2-8]. These negative properties are mainly caused by the high oxygen content present in the organic components. For this reason an upgrading step like catalytic hydrodeoxygenation (HDO) is often necessary. First studies on catalytic HDO were contributed by Elliott et al. in the eighties [7]. Nowadays the research in this field is very 
intense and widespread, as it can be indicated by the numerous publications reporting different catalysts, reaction conditions and reactor types [2-6].

Literature classifies the HDO process by the temperature into mild HDO and deep HDO [9]. A mild HDO runs up to $250{ }^{\circ} \mathrm{C}$ and aims to stabilize the oil, e.g. to improve storage properties or to lower acidity and reactivity. A deep $H D O$ can reach up to $400{ }^{\circ} \mathrm{C}$ with the target gain a high deoxygenation degree.

Nickel-based catalysts are generally considered to be most attractive for the industrial application of the HDO process [10]. Several noble metal catalysts, like Pt, Pd and $\mathrm{Ru}$, also seemed promising because they are often the first choice in hydrogenation reactions and are well investigated for the HDO reaction. Their HDO catalytic activity was characterized on model compounds [11] and raw pyrolysis oil as well $[9,12-15]$. Ruthenium was found to have a higher HDO activity than nickel, but its application is limited by the relative low abundance [16] and the high price [17].

A problematic issue with noble metal catalysts is also their high consumption of hydrogen, because they are very active for the hydrogenation of unsaturated bounds and aromatic rings. That makes an industrial-scaled process unfeasible. Further noble metals tend to get easily poisoned by the low amount of sulphur in the bio-oil [18, 19].

For these reasons a lot of literature is dealing with nickel-based catalysts and is trying to find an appropriate catalyst. A majority of these studies tested the catalysts on model compounds [20-25].

For example Bykova et al. [22] investigated the HDO reaction of guaiacol over $\mathrm{Ni} / \mathrm{ZrO}_{2}$ and $\mathrm{Ni} / \mathrm{SiO}_{2}$. Here the deep deoxygenation was carried out at $320{ }^{\circ} \mathrm{C}$ and 17.0 MPa of hydrogen pressure. The obtained main products were cyclohexane, 1-methyl-cyclohexane-1,2-diol and cyclohexanone.

Bykova et al. [22] also investigated the effect of temperature in the deoxygenation of guaiacol over nickel catalysts. The studied temperature range was $280-360^{\circ} \mathrm{C}$. It was found with increasing temperature, a higher deoxygenation degree was achieved. This suggests an enhanced cleavage of the $\mathrm{C}-\mathrm{O}$ bond at a higher temperature. However, also more coking occurs with increasing reaction temperature.

Mortensen et al. [24] performed a wide screening with a total of 23 different catalysts on phenol at $10.0 \mathrm{MPa}$ hydrogen pressure and $275{ }^{\circ} \mathrm{C}$. Nickel was tested on a variety of supports and among them zirconia showed the highest activity as a carrier material.

Further Mortensen et al. [24] focused on the HDO mechanism of supported nickel catalysts. Due to the fact that metallic nickel on activated carbon is nearly inactive, but on metal oxide supports such as $\mathrm{ZrO}_{2}, \mathrm{SiO}_{2}, \mathrm{TiO}_{2}$ or $\mathrm{Al}_{2} \mathrm{O}_{3}$ show a very high activity, a mechanism is proposed, in which the carrier is involved in the activation of the molecules for the hydrogenation and deoxygenation. Yakovlev et al. [26] already came to similar results and also pointed out the crucial role of the carrier in the reaction mechanism. The essential step may be the activation of phenol by a heterolytic cleavage of $\mathrm{H}-\mathrm{O}$ bond induced by a lewis-acid site on the oxidic carrier.

However, only few groups tested their catalysts with raw pyrolysis oil $[23,26,27]$. For this reason the systematic testing of nickel-based catalysts on raw pyrolysis oil was the objective of a previous work conduced in our institute [28]. In this work the mild HDO at $250{ }^{\circ} \mathrm{C}$ was deeply investigated and it was shown that nickelbased catalysts could be promising for the hydrotreatment process of raw pyrolysis oils. $\mathrm{Ru} / \mathrm{C}$ is still superior but too expensive and rare. A phase separation into polar and apolar molecules took place which favors a densification of energy and an isolation of platform molecules. The obtained oil phase was mildly deoxygenated in comparison to the raw pyrolysis oil (deoxygenation degree of 35-50\%, dry basis). The used metal-oxide carrier had a minor influence. The nickel-based catalysts showed all a similar $\mathrm{HDO}$ activity, only $\mathrm{NiCu} / \mathrm{Al}_{2} \mathrm{O}_{3}$ had a slightly better performance.

Besides, the approach of expansion of the liquid phase with carbon dioxide near the critical point is already known in heterogeneous catalysis [29]. Under near critical conditions the solubility of a gas in a liquid can increase by several orders of magnitude. The liquid phase can be expanded and changes its physical properties significantly. This physical state is called gas- expanded liquid (GXL). GXLs often have significantly improved properties such as a higher diffusion rate or a reduced viscosity. These two variables are crucial for an effective mass transfer. The solubility of other gases, such as hydrogen can be increased massively in a GXL. This means the gas used to expand the liquid phase (here $\mathrm{CO}_{2}$ ) does not take part to the reaction, but modifies the physical properties of the reaction system. The use of GXLs has scored in recent years special attention in terms of sustainable process intensification. The focus of a review by Subramaniam et al. [30] is hydroformylation and selective oxidations. Often, the conversion of reactions can be increased by overcoming mass transfer limitation, without diminishing the selectivity.

Also hydrogenation can be optimized by the use of GXLs. Bogel-Łukasik et al. [31] investigated the hydrogenation of $\beta$-myrcene with ruthenium and rhodium catalyst using $\mathrm{CO}_{2}$ as expansion gas. The hydrogen pressures varied between $2.0 \mathrm{MPa}$ and $4.5 \mathrm{MPa}$ and the total pressure was set to $12.5 \mathrm{MPa}$. Numerous outcomes like yield 
and selectivity of the reaction could be tuned as desired by varying the expansion parameters.

Jenab and Temelli [32] expanded various vegetable oils with $\mathrm{CO}_{2}$ at $70{ }^{\circ} \mathrm{C}$ and pressures up to $25.0 \mathrm{MPa}$, while volume changes of up to $+43 \%$ were observed. Their research also aimed to intensify and optimize the catalytic hydrogenation of vegetable oils.

For the first reaction steps in hydrodeoxygenation (stabilization followed by deoxygenation) the hydrogen transfer rate can be limiting [9]. Since the hydrodeoxygenation competes with the polymerization, an acceleration of the mass transfer or an increase in the hydrogen concentration in the pyrolysis oil for the deoxygenation would be beneficial. Our work matched the approach of GXL-enhanced catalysis with the hydrodeoxygenation of pyrolysis oils. Therefore we first tested the pyrolysis oil/ $\mathrm{CO}_{2}$ system by measuring its rheological and volumetric behavior. Afterwards we accomplished a hydrodeoxygenation over $\mathrm{Ni} / \mathrm{Al}_{2} \mathrm{O}_{3}$, monitoring the effect of the $\mathrm{CO}_{2}$ partial pressure on the reaction at 250 and $340{ }^{\circ} \mathrm{C}$.

\section{Results and discussion}

Effect of $\mathrm{CO}_{2}$ on the physical properties of the pyrolysis oil An essential characteristic of pyrolysis oil is the strong temperature dependence of the viscosity. Between 55 and $90{ }^{\circ} \mathrm{C}$, the viscosity decreased without the use of carbon dioxide to $20 \%$ of the original value at lower temperature (Fig. 1). The influence of carbon dioxide on the viscosity is also very strong. At $52{ }^{\circ} \mathrm{C}$, a $\mathrm{CO}_{2}$ pressure of $0.5 \mathrm{MPa}$ permitted to reduce the viscosity by $30 \%$ in comparison to the experiment where no $\mathrm{CO}_{2}$ was employed. With $4.0 \mathrm{MPa}$ of $\mathrm{CO}_{2}$ the viscosity fell by $60 \%$. So the properties of pyrolysis by the expansion of carbon dioxide

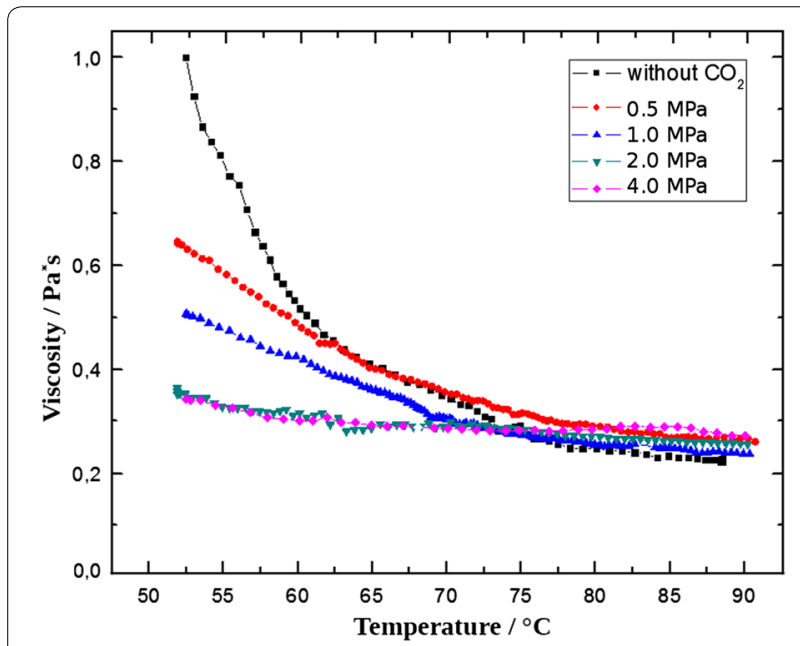

Fig. 1 Dynamic viscosity of pyrolysis oil as a function of the temperature are mutable, which is why an influence on the catalytic deoxygenation is conceivable. The reduction in viscosity became marginal above $70{ }^{\circ} \mathrm{C}$ because here the temperature dependency has the strongest effect. Anyway, this does not argue against an influence of carbon dioxide above $70{ }^{\circ} \mathrm{C}$ on properties such as diffusion rate or surface tension.

The observed volume expansion with $\mathrm{CO}_{2}$ was very low. Only with supercritical carbon (measurement at $8.0 \mathrm{MPa}, 60^{\circ} \mathrm{C}$ ) a significant expansion of approximately $+5 \%$ could be achieved. When liquid or gaseous carbon dioxide was used, the volume change was negligible. However, a quite high amount of $\mathrm{CO}_{2}$ seemed to be dissolved in the oil. After gas release we observed always a quick foam-like expansion through fine gas bubbles released from the oil (Fig. 2).

\section{Hydrogen consumption}

The activity of $\mathrm{Ni} / \mathrm{Al}_{2} \mathrm{O}_{3}$ in different conditions is reported as normal liters of hydrogen consumed during the reaction per kilogram of pyrolysis oil (Table 1). The values were all quite similar and have an average of $54 \mathrm{NL}_{\mathrm{H} 2} / \mathrm{kg}_{\mathrm{PO}}$ at $250{ }^{\circ} \mathrm{C}$ and $72 \mathrm{NL}_{\mathrm{H} 2} / \mathrm{kg}_{\mathrm{PO}}$ at $340{ }^{\circ} \mathrm{C}$. No trend could be observed when using $\mathrm{CO}_{2}$, but ${ }^{1} \mathrm{H}-\mathrm{NMR}$ and elemental analysis indicate a slightly lower activity for hydrogenation. In the blank test (no catalyst used, 40 bar $\mathrm{H}_{2}$ and 40 bar $\mathrm{CO}_{2}$ ) at $340{ }^{\circ} \mathrm{C}$ we observed blind activity with a hydrogen consumption of $50 \mathrm{NL}_{\mathrm{H} 2} / \mathrm{kg}_{\mathrm{PO}}$. At $250{ }^{\circ} \mathrm{C}$ the blind activity was negligible $\left(2 \mathrm{NL}_{\mathrm{H} 2} / \mathrm{kg}_{\mathrm{PO}}\right)$.

\section{Mass balance and elemental analysis of the products}

The main products at $250^{\circ} \mathrm{C}$ were an aqueous phase $(80$ $82 \%)$ and an oil phase (7-9\%). The oil phase had a higher density than the aqueous one at $250^{\circ} \mathrm{C}$, while at $340{ }^{\circ} \mathrm{C}$ it was the opposite. At $340{ }^{\circ} \mathrm{C}$ more oil phase (12-13\%) was produced and less aqueous phase (73-77\%).

The losses during the recovery were in the range 3-8\%. The production of gases and solids was limited to small percentages (1-2\%), mainly coke, $\mathrm{CO}_{2}$ and negligible amounts of lower hydrocarbons (e.g. $\mathrm{CH}_{4}$ ).

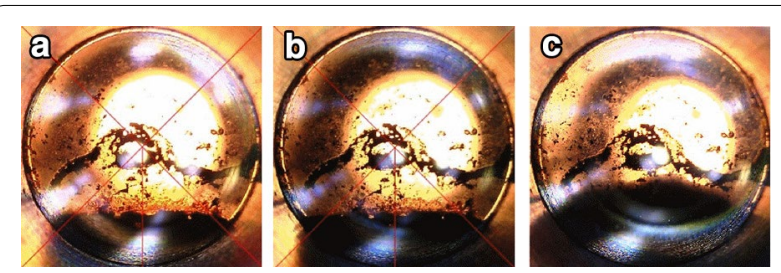

Fig. 2 Volumetric expansion measurements of pyrolysis oil under $\mathrm{CO}_{2}$ atmosphere. Comparison of the oil level: a $8.0 \mathrm{MPa} \mathrm{CO}_{2}$ at $60^{\circ} \mathrm{C}$ right after oil charging, b $8.0 \mathrm{MPa} \mathrm{CO}{ }_{2}$ at $60^{\circ} \mathrm{C}$ for $72 \mathrm{~h}$, c after gas release 
Table 1 Hydrogen consumption of all HDO experiments

\begin{tabular}{|c|c|c|c|}
\hline $\mathrm{T}\left({ }^{\circ} \mathrm{C}\right)$ & $\mathrm{p}_{\mathrm{CO} 2}(\mathrm{MPa})$ & Type & $\Delta \mathrm{V}_{\mathrm{H} 2}\left(\mathrm{NL}_{\mathrm{H} 2 /} \mathrm{kg}_{\mathrm{PO}}\right)$ \\
\hline 250 & 0.0 & $\mathrm{Ni} / \mathrm{Al}_{2} \mathrm{O}_{3}$ & 44 \\
\hline 250 & 2.0 & $\mathrm{Ni} / \mathrm{Al}_{2} \mathrm{O}_{3}$ & 67 \\
\hline 250 & 4.0 & $\mathrm{Ni} / \mathrm{Al}_{2} \mathrm{O}_{3}$ & 50 \\
\hline 250 & 4.0 & Blank & 2 \\
\hline 340 & 0.0 & $\mathrm{Ni} / \mathrm{Al}_{2} \mathrm{O}_{3}$ & 76 \\
\hline 340 & 2.0 & $\mathrm{Ni} / \mathrm{Al}_{2} \mathrm{O}_{3}$ & 58 \\
\hline 340 & 4.0 & $\mathrm{Ni} / \mathrm{Al}_{2} \mathrm{O}_{3}$ & 82 \\
\hline 340 & 4.0 & Blank & 50 \\
\hline
\end{tabular}

The aqueous phases of all the reactions at $250{ }^{\circ} \mathrm{C}$ had a similar content in water (70.3-72.1\%) while the oil products contained $9.2-14.5 \%$ water. The pyrolysis oil initially contained $58.3 \%$ water. At $340{ }^{\circ} \mathrm{C}$ the water content increases in the aqueous phase (80.3-82.3\%) with regard to $250{ }^{\circ} \mathrm{C}$. This can be interpreted as a more effective deoxygenation/hydrogenation and also a more intensive phase separation. The dry mass captured from the pyrolysis oil into the oil phase is significantly higher at $340{ }^{\circ} \mathrm{C}$ than at $250{ }^{\circ} \mathrm{C}$ ( 45 vs. $25 \%$ in average).

The expansion with $\mathrm{CO}_{2}$ showed no effect on yield or water content at both temperatures. Further, we detected no relevant amounts of methane. We conclude that $\mathrm{Ni}$ / $\mathrm{Al}_{2} \mathrm{O}_{3}$ did not hydrogenate $\mathrm{CO}_{2}$ to methane although the used catalyst can favor the methanation [33].

The results from elemental analysis and Karl Fischer titration were elaborated and the calculated molar ratios $\mathrm{H}: \mathrm{C}$ and O:C (dry basis) are shown in the Van Krevelen plot which is used to judge and interpret the quality of fossil fuels like crude oil (Fig. 3). With higher HDO

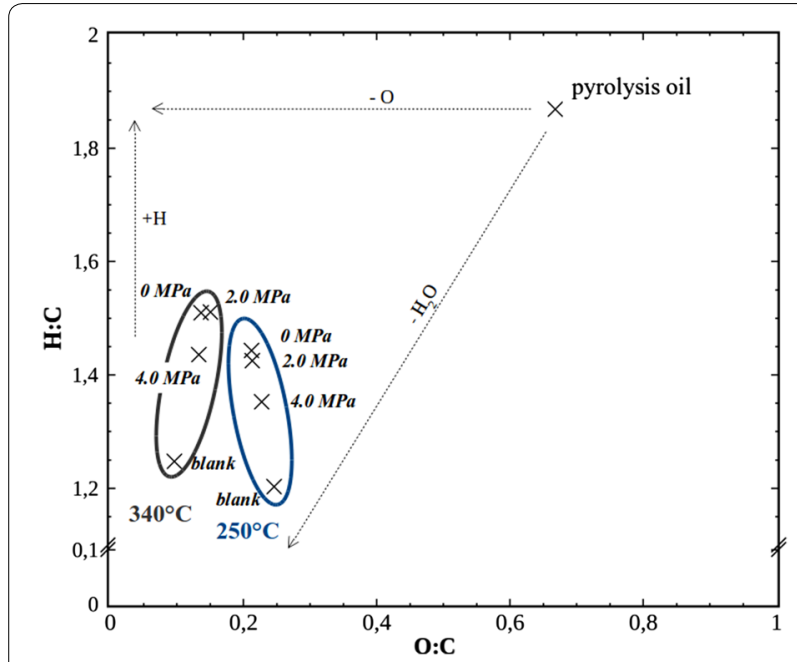

Fig. 3 Van-Krevelen-plot of raw pyrolysis oil (feed) and the HDO reaction products from different temperatures and $\mathrm{CO}_{2}$ atmospheres (catalyst: $\mathrm{Ni} / \mathrm{Al}_{2} \mathrm{O}_{3}$ ) temperature the values shift to higher $\mathrm{H}: \mathrm{C}$ ratios and lower $\mathrm{O}: \mathrm{C}$ ratios. Taking the separation in two phases into account, we observed a combination of hydrodeoxygenation reactions and of the repartition of more apolar compounds in the upgraded oil. The blank test shows lower content of hydrogen, but the oxygen content is similar to the experiments with $\mathrm{Ni} / \mathrm{Al}_{2} \mathrm{O}_{3}$.

The only observed effect when using $\mathrm{CO}_{2}$ was a decrease of the hydrogenation with decreasing partial pressure of hydrogen in the mixture, both at 250 and $340^{\circ} \mathrm{C}$.

The deoxygenation with $\mathrm{Ni} / \mathrm{Al}_{2} \mathrm{O}_{3}$ was successful, but the expansion with $\mathrm{CO}_{2}$ was not improving the $\mathrm{HDO}$ process in comparison to earlier works [28]. The oxygen content was reduced from $43.5 \%$ (dry basis) in the raw pyrolysis oil to $20-22 \%$ (dry basis) in the oil phase obtained at $250{ }^{\circ} \mathrm{C}$ and to $14-15 \%$ in the oil phase obtained at $340{ }^{\circ} \mathrm{C}$. In terms of deoxygenation degree this corresponds to $51-54 \%$ of oxygen removed from the organic components at $250{ }^{\circ} \mathrm{C}$. The deep deoxygenation at $340{ }^{\circ} \mathrm{C}$ reached $66-69 \%$ in the oil phase.

\section{Chemical composition of the products}

The chemical composition of the oil phase changes significantly in comparison to the raw pyrolysis oil. At $250{ }^{\circ} \mathrm{C}$ the concentration of protons assigned to water and free hydroxyl groups is reduced from 70 to $20 \mathrm{~mol} / \mathrm{kg}$ (Fig. 4), and at $340{ }^{\circ} \mathrm{C}$ even further to $10 \mathrm{~mol} / \mathrm{kg}$. The concentration of protons assigned to alkyl groups and $\alpha-\mathrm{H}$ atoms of carbonyl groups and unsaturated groups form the majority of the hydrogen species. Also protons bound to aromatics are present in the organic phases with $5-10 \mathrm{~mol} /$ $\mathrm{kg}$. With increasing temperature the concentration of

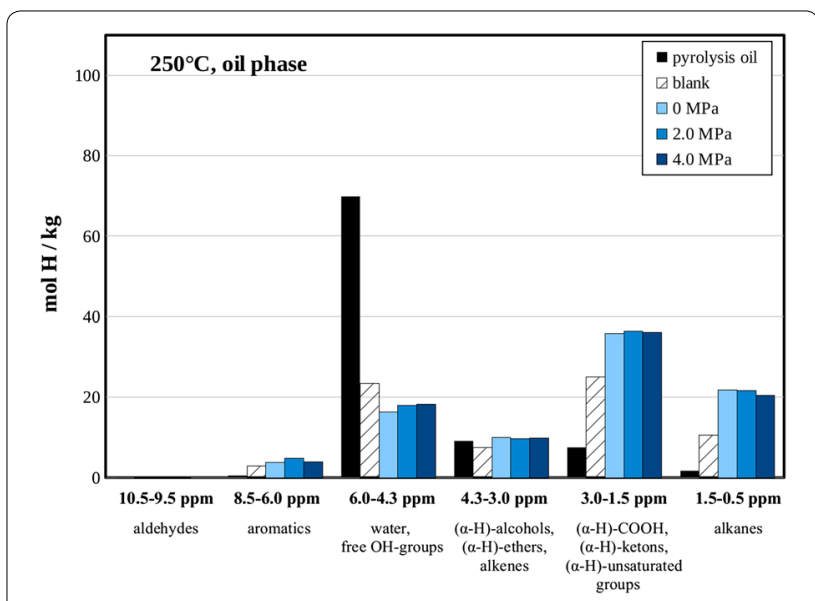

Fig. 4 Integration of the ${ }^{1} \mathrm{H}-\mathrm{NMR}$ signal of the oil phase obtained at $250^{\circ} \mathrm{C}$ under various $\mathrm{CO}_{2}$ pressures (reported as mols of protons per kilogram of sample and integrated in typical regions of specific functional groups) 
protons assigned to polar groups is reduced and the concentration of protons assigned to aliphatic and polar groups increases.

There is only a weak trend in chemical nature with increasing partial pressure of $\mathrm{CO}_{2}$. The concentration of protons assigned aliphatics decreases at $340{ }^{\circ} \mathrm{C}$ in the oil phase due to the lower partial pressure of hydrogen (Fig. 5). Similarly, the concentration of protons assigned to oxygen-containing groups increases (water, free $\mathrm{OH}-$ groups, alcohols, ethers, $\alpha-\mathrm{H}$ atoms of carbonyl groups).

The chemical nature in the aqueous phases is not significantly changed by the HDO reaction at both temperatures. Only the concentration of protons assigned to water and free hydroxyl groups increases sharply. They increased at $250^{\circ} \mathrm{C}$ in all experiments on about $90 \mathrm{~mol} / \mathrm{kg}$ and at $340{ }^{\circ} \mathrm{C}$ even further, to about $95 \mathrm{~mol} / \mathrm{kg}$. At $250{ }^{\circ} \mathrm{C}$ the concentrations of all kind of protons remained almost unchanged in their concentration (Fig. 6). At $340{ }^{\circ} \mathrm{C}$ a slight decrease in the concentration of protons assigned to oxygen-containing groups (alcohols, ethers, ketones and carboxylic acids) can be seen (Fig. 7).

By GC-MS we found mainly acetic acid, propionic acid, hydroxypropanone and levoglucosan in the raw pyrolysis oil and in the aqueous phases. All these substances are typical pyrolysis products from cellulose and hemicellulose. Some furans and furfurals were also present in the investigated oil. Typical lignin fragments could be found, like phenol, guaiacol and syringol. Also numerous other phenol derivatives were present. Many unidentifiable compounds had molecular weights between 200 and $300 \mathrm{~g} / \mathrm{mol}$.

In the organic phase we additionally found many phenol derivatives having two to three methyl or ethyl groups. The organic phases, which were obtained at

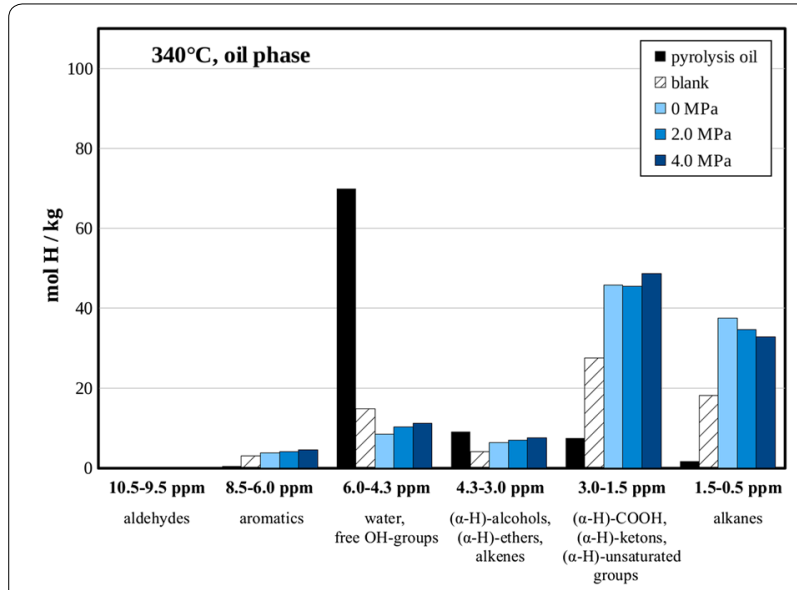

Fig. 5 Integration of the ${ }^{1} \mathrm{H}-\mathrm{NMR}$ signal of the oil phase obtained at $340^{\circ} \mathrm{C}$ under various $\mathrm{CO}_{2}$ pressures (reported as mols of protons per kilogram of sample and integrated in typical regions of specific functional groups)

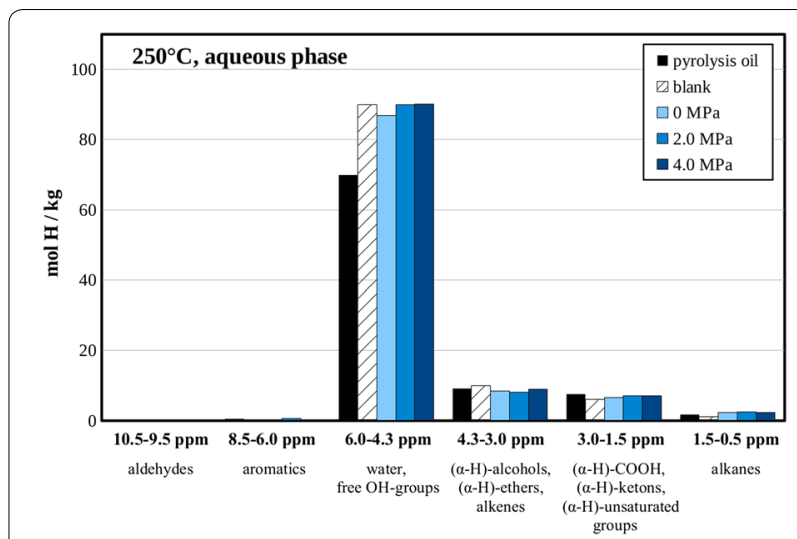

Fig. 6 Integration of the ${ }^{1} \mathrm{H}-\mathrm{NMR}$ signal of the aqueous phase obtained at $250^{\circ} \mathrm{C}$ under various $\mathrm{CO}_{2}$ pressures (reported as mols of protons per kilogram of sample and integrated in typical regions of specific functional groups)

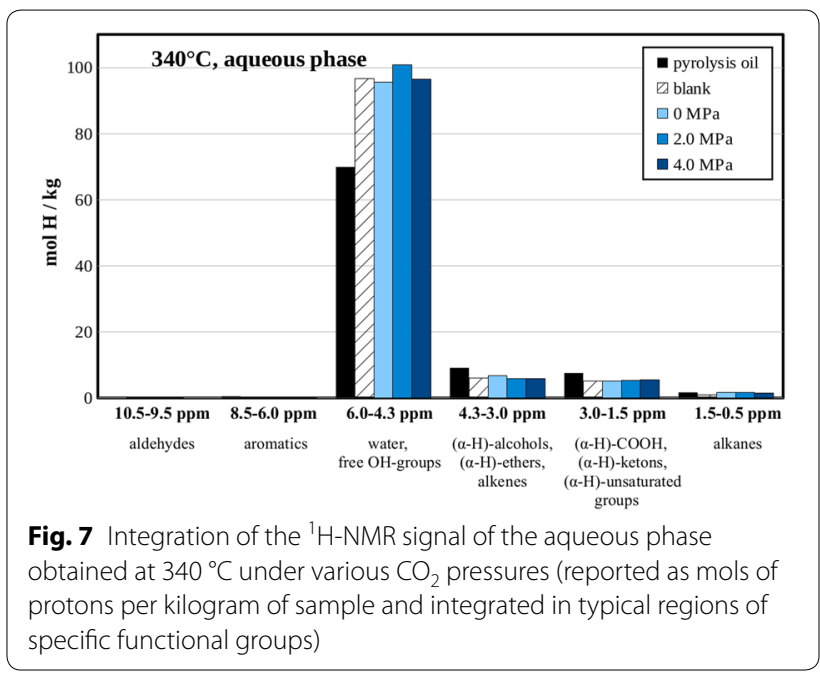

$340{ }^{\circ} \mathrm{C}$ on $\mathrm{Ni} / \mathrm{Al}_{2} \mathrm{O}_{3}$, also contained some cyclic and saturated hydrocarbons resulting from the hydrogenation of aromatic compounds. Partially the side chains on the ring are completely hydrogenated or deoxygenated, but still some ketones or hydroxyl groups remain. The following substances are clearly identified: 2-methylcyclopentanone, cyclohexanone, 3-methyl-cyclopentene, methylene-cyclohexane and cyclopentanol.

Further reaction products come from ring-opening reactions of heterocyclic compounds (such as furfurals). They can be described as linear or sparsely branched, saturated chains with 5-6 carbon atoms and 1-3 hydroxylic or caboxylic groups (e.g. hexan-2-one). From the analysis of the chemical compositions of the products we concluded that $\mathrm{CO}_{2}$ has no direct influence on product distribution. The reasons are speculative. For instance it is conceivable that the solubility of hydrogen 
in the pyrolysis oil stays low due to the high temperature. The rheological measurements already showed that with higher temperature the GXL-effect on viscosity is decreased. We suspect the same trend in hydrogen solubility. However, the mass-transfer limitation could not be overcome, neither diminished, by adding carbon dioxide to the mixture.

\section{Experimental}

Two different pyrolysis oils were used in our work. Their physical-chemical properties are reported in Table 2 . For the measurement of rheological properties and volume expansion, we used a high viscous, tar-like pyrolysis oil because GXL effects with $\mathrm{CO}_{2}$ can be detected with higher certainty if the oil is more viscous. The HDO experiments were accomplished with a low viscous, polar pyrolysis oil which was already used before in HDO experiments in our institute. That makes the results easier to compare to results with earlier works [28]. Both pyrolysis oils were produced in the bioliq ${ }^{\circledR}$ pilot plant at KIT, Germany.

\section{Rheological measurements}

The apparatus used in this work to measure viscosity and rheological behavior was a rotational rheometer (Rheometer R/S+, BROOKFIELD) controlled by computer software (RHEO 3000). Measurements were performed inside a high pressure cell (500 $\mathrm{mL}$ total volume) and the temperature was controlled by a thermostatic oil bath (HAAKE). A double gap cylinder measure system (PN$80 \mathrm{RT}$, inner cylinder radius $0.01925 \mathrm{~m}$, outer cylinder radius $0.01972 \mathrm{~m}$ ) inside the pressure cell was coupled with the rheometer magnetically.

During previous experiments, an intensive aging problem of the pyrolysis oil has been observed. At $148^{\circ} \mathrm{C}$, the

Table 2 Properties of the used pyrolysis oils

\begin{tabular}{lll}
\hline & $\begin{array}{l}\text { Oil used for the } \\
\text { measurement of } \\
\text { physical properties }\end{array}$ & $\begin{array}{l}\text { Oil used for } \\
\text { HDO experiments }\end{array}$ \\
\hline wt\% $\mathrm{H}_{2} \mathrm{O}$ & 16.8 & 58.3 \\
Wet basis & & \\
$\mathrm{wt} \% \mathrm{C}$ & 57.5 & 20.4 \\
$\mathrm{wt} \% \mathrm{O}$ & 35.6 & 70 \\
$\mathrm{wt} \% \mathrm{H}$ & 6.9 & 9.7 \\
Dry basis & & \\
$\mathrm{wt} \% \mathrm{C}$ & 69.1 & 48.9 \\
$\mathrm{wt} \% \mathrm{O}$ & 24.8 & 43.5 \\
$\mathrm{wt} \% \mathrm{H}$ & 6.0 & 7.6 \\
Density & $1.13 \mathrm{~kg} / \mathrm{l}$ & $1.11 \mathrm{~kg} / \mathrm{l}$ \\
pH value & Organic phase, not measureable & 4 \\
\hline
\end{tabular}

viscosity of the pyrolysis oil increased by $40 \%$ within $45 \mathrm{~min}$. Holding this temperature for $3 \mathrm{~h}$, increases the viscosity by 30 times and turns the pyrolysis oil into a crispy solid. Fast aging at altered temperature is also known in literature. Ortega et al. reported that such an agening also takes place within 1-7 days at temperatures between 60 and $90{ }^{\circ} \mathrm{C}$ [34].

However, at a temperature below $90{ }^{\circ} \mathrm{C}$, this phenomenon was insignificant. In order to avoid deviation caused by oil aging, measurements were conducted under $90{ }^{\circ} \mathrm{C}$ and for relative short time. For each experiment, fresh pyrolysis oil was used. The shear rate was always set to $100 \mathrm{~s}^{-1}$. The temperature was varied between 50 and $90^{\circ} \mathrm{C}$.

For measuring the GXL-effect, the oil samples were first heated to $52{ }^{\circ} \mathrm{C}$. When their viscosity stabilized, $\mathrm{CO}_{2}$ of certain pressure $(0.5,1.0$ and $2.0 \mathrm{MPa})$ was filled into the cell and the gas diffusion began. In the following 180-240 $\mathrm{min}$, the viscosity changes of these samples were recorded. Depending from the temperature and $\mathrm{CO}_{2}$ pressure the diffusion of $\mathrm{CO}_{2}$ into the oil was complete after 80-160 min.

\section{Volumetric expansion measurements}

Volumetric expansion measurements were carried out using a high pressure view cell. The cell had a capacity of $15 \mathrm{~mL}$ and was equipped with sapphire windows on both sides. A light source and a digital camera (Supereyes B008, Shenzhen D\&F Co.) were placed on the two opposite windows. The cell was surrounded by a heating jacket connected to a thermostatic circulating oil bath (HAAKE C35P). Pressured $\mathrm{CO}_{2}$ was driven into the cell through an automatic pump (Teledyne ISCO D-series).

In order to lower the viscosity of the pyrolysis oil for an easier sample charging, the oil sample was first heated to $50{ }^{\circ} \mathrm{C}$ and then injected into the cell through a liquid inlet. The cell was loaded with oil to about one-quarter of the volume.

The volume expansion experiments were accomplished with three states of $\mathrm{CO}_{2}$ : gas, liquid and supercritical. To keep $\mathrm{CO}_{2}$ in gas phase, the temperature in the cell was set above $40{ }^{\circ} \mathrm{C}$. The pressure was set to 4.0 or $6.0 \mathrm{MPa}$. The liquid state was measured at 15 and $8.0 \mathrm{MPa}$. To ensure supercritical state $8.0 \mathrm{MPa}$ of $\mathrm{CO}_{2}$ pressure and $40{ }^{\circ} \mathrm{C}$ were used. For all three states the cell was kept under pressure and observed for $72 \mathrm{~h}$ in case long-time effects occurs or the equilibrium is reached very slow.

\section{Catalyst preparation}

An industrial nickel catalyst $\left(\mathrm{METH}^{\circledR} 134,25 \pm 1 \%\right.$ nickel oxide on alumina, C\&CS) which is actually a commercial methanation catalyst was used. The reduction was accomplished in a heated reaction tube at $500{ }^{\circ} \mathrm{C}$ for $4 \mathrm{~h}$ by a gas mixture of $50 \%$ hydrogen in nitrogen at a 
flow rate of $2.6 \mathrm{NL} / \mathrm{min}$. The catalysts raw material were crushed and sieved to obtain a uniform particle size fraction in the range of $0.25-0.50 \mathrm{~mm}$.

\section{HDO reaction}

For the HDO experiments, two $200 \mathrm{ml}$ batch reactors were used. Both were built in the KIT-IKFT workshop. For each run we used $50 \mathrm{~mL}$ pyrolysis oil and $2.5 \mathrm{~g}$ catalyst powder. The reactor was always flushed with nitrogen for $10 \mathrm{~min}$ (Air Liquid Alphagaz ${ }^{\mathrm{TM}}$ 6.0) to remove oxygen and avoid explosive mixtures with hydrogen. After flushing, the reactor was pressurized. The reactor was charged with $\mathrm{CO}_{2}$ (Air Liquid Alphagaz ${ }^{\mathrm{TM}}$ 6.0) first. The set pressure corresponds to the partial pressure of carbon dioxide in the mixture $(0.0 \mathrm{MPa}, 2.0 \mathrm{MPa}, 4.0 \mathrm{MPa})$. Next, hydrogen (Air Liquid Alphagaz ${ }^{\mathrm{TM}}$ 6.0) was added. The absolute total pressure was always $8.0 \mathrm{MPa}$ at room temperature.

The reaction time was $2 \mathrm{~h}$, including the ramp $\left(5^{\circ} \mathrm{C} /\right.$ min for $250{ }^{\circ} \mathrm{C}, 15{ }^{\circ} \mathrm{C} / \mathrm{min}$ for $340{ }^{\circ} \mathrm{C}$ ). The agitator was running during the reaction time at $1000 \mathrm{rpm}$. The experiments were run all isochorically and under autogenous pressure. The pressures reached $15.0-20.5 \mathrm{MPa}$ at $250{ }^{\circ} \mathrm{C}$ and $25.0-32.5 \mathrm{MPa}$ at $340^{\circ} \mathrm{C}$. After the reaction time the reactor was rapidly quenched.

\section{Conclusions}

In summary, a successful hydrodeoxygenation was achieved, in terms of yield of deoxygenated oil phase and deoxygenation degree. However, the expansion with $\mathrm{CO}_{2}$ did not improve the deoxygenation degree. Despite the rheological and volumetric properties changed at lower temperatures, no significant GXL effect on the HDO reaction could be observed. Classical GXL catalysis is usually performed under milder conditions. We suspect that the chosen temperature was too high to reach a significant physical enhancement. Therefore these pioneer experiments were a useful contribution to find the limits in the process conditions for an effective gas expansion. We suspect the GXL effect to more intense at lower temperatures. Further studies will check this theory. However, no negative effect could be observed, except an indirect decrease of the hydrogenation reactions due to the lower partial pressure of hydrogen.

In future bio-refineries a recycle of hydrogen gas will be inevitable. Our work shows that mixtures of hydrogen and carbon dioxide can be used for catalytic hydrodeoxygenation as well as pure hydrogen. The carbon dioxide in the mixture does not interfere with the HDO reaction or the nickel-based catalyst. Due to the high reaction temperatures in HDO processes, decarboxylation reactions take place releasing $\mathrm{CO}_{2}$. For a direct recycle it would be favorable if this mixture of $\mathrm{CO}_{2}$ and excess hydrogen can be used without impair the HDO reaction. Other sources of such mixtures are e.g. water-gas shift reaction or the decomposition of formic acid. Another positive discovery favoring the use of such mixtures is that $\mathrm{Ni} / \mathrm{Al}_{2} \mathrm{O}_{3}$ is not active for the methanation of $\mathrm{CO}_{2}$ when its is used together with pyrolysis oil under the conditions of this work.

\section{Methods \\ Gas phase analysis}

Gas chromatography (GC) was used to determine the mol fraction of the process gases $\left(\mathrm{H}_{2}, \mathrm{CO}_{2}\right)$ and side products (e.g. $\left.\mathrm{CH}_{4}\right)$ in the gas phase after the reaction. The GC we used was a 6890 Agilent with two switchable columns (Restek 57096 Hayesep Q and Resteck Molsieve 5A). Two detectors were built in: a FID (flame ionisation detector) and a TCD (thermal conductivity detector).

\section{Water content}

The water content of the liquid products is expressed as mass fraction and was determined by the Karl Fischer titration. The titrator used is an 841 Titrando from Metrohm.

\section{Elemental analysis}

For this purpose, an elemental analyzer (CHN628, Leco) was used which measures the content of carbon, hydrogen and nitrogen. The mass fraction of oxygen is calculated as the difference between $100 \%$ and the percentage of the other elements.

\section{Quantitative ${ }^{1} \mathrm{H}-\mathrm{NMR}$ spectroscopy}

For a more detailed analysis of the chemical structures in the liquid samples a quantitative hydrogen-nuclear magnetic resonance spectroscopy ( $\left.{ }^{1} \mathrm{H}-\mathrm{NMR}\right)$ was applied. For pyrolysis and deoxygenated oils the method is appropriate and is proposed as a method of analysis of pyrolysis oils in the literature [35]. The parameters and method are the same as in our previous work [28].

\section{GC-MS}

In order to identify components and reaction products, a gas chromatography with coupled mass spectrometry (GC-MS) was applied. For this purpose, the solutions of the samples from the ${ }^{1} \mathrm{H}-\mathrm{NMR}$ ) measurements were used. The samples were filtered before the measurement (Teflon ${ }^{\circledR}$ pore size $0.2 \mu \mathrm{m}$ ). We used a HP 1800A Gas Chromatograph with a Stabilwax ${ }^{\circledR}$ column. The mass spectrometer used was an HP 5971. The mass spectra were analyzed with a computer and were compared to a database to identify individual chemical compounds. 


\section{Authors' contributions}

$\mathrm{HZ}$ and $\mathrm{KR}$ accomplished and interpreted the rheological and volumetric expansion measurements. All HDO-related works were carried out by WO and CB. JS and ND coordinated our HDO and GXL research and helped to design this study. The manuscript was mainly drafted by WO. HZ contributed the parts concerning rheological and volumetric measurement. The manuscript was revised by $C B$ and KR. All authors read and approved the final manuscript.

\section{Author details}

${ }^{1}$ Karlsruhe Institute of Technology, Institute of Catalysis Research and Technology, Hermann-von-Helmholtz-Platz 1, 76344 Eggenstein-Leopoldshafen, Germany. ${ }^{2}$ Heidelberg University, Grabengasse 1, 69117 Heidelberg, Germany.

\section{Acknowledgements}

The authors would like to thank the Helmholtz Research School EnergyRelated Catalysis for financial support. Further acknowledgement goes to the analytics department of IKFT, especially B. Rolli, G. Zwick, A. Lautenbach, H. Köhler, J. Maier, J. Heinrich, D. Neumann-Walter and A. Beilmann (ITCP$\mathrm{KIT})$. We are equally thankful for E. Kehrwecker and V. Meinzer. Their teams in the mechanical and electrical workshop were always an essential, valuable support.

\section{Competing interests}

The authors declare that they have no competing interests.

Received: 31 January 2016 Accepted: 29 May 2016

Published online: 23 June 2016

\section{References}

1. Kamm B, Kamm M (2004) Biorefinery-systems. Chem Biochem Eng Q 18:1-7

2. Mortensen PM, Grunwaldt J-D, Jensen PA, Knudsen KG, Jensen AD (2011) A review of catalytic upgrading of bio-oil to engine fuels. Appl Catal Gen 407:1-19

3. Furimsky E (2000) Catalytic hydrodeoxygenation. Appl Catal Gen 199:147-190

4. Furimsky E (2013) Hydroprocessing challenges in biofuels production. Catal Today 217:13-56

5. Bu Q, Lei H, Zacher AH, Wang L, Ren S, Liang J, Wei Y, Liu Y, Tang J, Zhang Q, Ruan R (2012) A review of catalytic hydrodeoxygenation of ligninderived phenols from biomass pyrolysis. Bioresour Technol 124:470-477

6. Bulushev DA, Ross JRH (2011) Catalysis for conversion of biomass to fuels via pyrolysis and gasification: a review. Catal Today 171:1-13

7. Elliott DC (2007) Historical developments in hydroprocessing bio-oils. Energy Fuels 21:1792-1815

8. Kan T, Strezov V, Evans TJ (2016) Lignocellulosic biomass pyrolysis: a review of product properties and effects of pyrolysis parameters. Renew Sustain Energy Rev 57:1126-1140

9. Venderbosch Rh, Ardiyanti Ar, Wildschut J, Oasmaa A, Heeres Hj (2010) Stabilization of biomass-derived pyrolysis oils. J Chem Technol Biotechnol 85:674-686

10. Solantausta Y, Albemarle C: Co-processing of upgraded bio-liquids in standard refinery units-BIOCOUP. In: European Conference on Biorefinery Research, Helsinki. vol 19; 2006:20

11. Gutierrez A, Kaila RK, Honkela ML, Slioor R, Krause AOI (2009) Hydrodeoxygenation of guaiacol on noble metal catalysts. Catal Today 147:239-246

12. Ardiyanti AR, Gutierrez A, Honkela ML, Krause AOI, Heeres HJ (2011) Hydrotreatment of wood-based pyrolysis oil using zirconia-supported mono- and bimetallic (Pt, Pd, Rh) catalysts. Appl Catal Gen 407:56-66

13. Wildschut J, Mahfud FH, Venderbosch RH, Heeres HJ (2009) Hydrotreatment of fast pyrolysis oil using heterogeneous noble-metal catalysts. Ind Eng Chem Res 48:10324-10334

14. French RJ, Black SK, Myers M, Stunkel J, Gjersing E, lisa K (2015) Hydrotreating the organic fraction of biomass pyrolysis oil to a refinery intermediate. Energy Fuels 29:7985-7992
15. Gollakota ARK, Reddy M, Subramanyam MD, Kishore N (2016) A review on the upgradation techniques of pyrolysis oil. Renew Sustain Energy Rev 58:1543-1568

16. Lide DR: CRC handbook of chemistry and physics, 85th Edition. CRC Press; 2004

17. Ruthenium. In: Nature's building blocks: an A-Z guide to the elements. New Rev Up edition. Oxford ; New York: Oxford University Press; 2011:368-370

18. Bartholomew CH (2001) Mechanisms of catalyst deactivation. Appl Catal Gen 212:17-60

19. Elliott DC (2015) Biofuel from fast pyrolysis and catalytic hydrodeoxygenation. Curr Opin Chem Eng 9:59-65

20. Echeandia S, Arias PL, Barrio VL, Pawelec B, Fierro JLG (2010) Synergy effect in the $\mathrm{HDO}$ of phenol over $\mathrm{Ni}-\mathrm{W}$ catalysts supported on active carbon: effect of tungsten precursors. Appl Catal B Environ 101:1-12

21. Zhao C, Kou Y, Lemonidou AA, Li X, Lercher JA (2010) Hydrodeoxygenation of bio-derived phenols to hydrocarbons using RANEY ${ }^{\circledR} \mathrm{Ni}$ and Nafion/SiO2 catalysts. Chem Commun 46:412-414

22. Bykova MV, Ermakov DY, Kaichev V, Bulavchenko OA, Saraev AA, Lebedev MY, Yakovlev VA (2012) Ni-based sol-gel catalysts as promising systems for crude bio-oil upgrading: guaiacol hydrodeoxygenation study. Appl Catal B Environ 113-114:296-307

23. Ardiyanti AR, Khromova SA, Venderbosch RH, Yakovlev VA, MeliánCabrera IV, Heeres HJ (2012) Catalytic hydrotreatment of fast pyrolysis oil using bimetallic Ni-Cu catalysts on various supports. Appl Catal Gen 449:121-130

24. Mortensen PM, Grunwaldt J-D, Jensen PA, Jensen AD (2013) Screening of catalysts for hydrodeoxygenation of phenol as a model compound for bio-oil. ACS Catal 3:1774-1785

25. Bykova MV, Zavarukhin SG, Trusov LI, Yakovlev VA (2013) Guaiacol hydrodeoxygenation kinetics with catalyst deactivation taken into consideration. Kinet Catal 54:40-48

26. Yakovlev VA, Khromova SA, Sherstyuk OV, Dundich VO, Ermakov DY, Novopashina VM, Lebedev MY, Bulavchenko O, Parmon VN (2009) Development of new catalytic systems for upgraded bio-fuels production from bio-crude-oil and biodiesel. Catal Today 144:362-366

27. Ardiyanti AR, Khromova SA, Venderbosch RH, Yakovlev VA, Heeres HJ (2012) Catalytic hydrotreatment of fast-pyrolysis oil using non-sulfided bimetallic Ni-Cu catalysts on a $\delta$-Al2O3 support. Appl Catal B Environ 117-118:105-117

28. Boscagli C, Raffelt K, Olbrich W, Zevaco T, Otto T, Grunwaldt J-D, Sauer $J$ (2015) Mild hydrotreatment of the light fraction of fast-pyrolysis oil produced from straw over nickel-based catalysts. Biomass Bioenergy 83:525-538

29. Subramaniam B, Chaudhari RV, Chaudhari AS, Akien GR, Xie Z (2014) Supercritical fluids and gas-expanded liquids as tunable media for multiphase catalytic reactions. Chem Eng Sci 115:3-18

30. Subramaniam B, Akien GR (2012) Sustainable catalytic reaction engineering with gas-expanded liquids. Curr Opin Chem Eng 1:336-341

31. Bogel-Łukasik E, Wind J, Bogel-Łukasik R, da Ponte MN (2010) The influence of hydrogen pressure on the heterogeneous hydrogenation of $\beta$-myrcene in a CO 2-expanded liquid. J Supercrit Fluids 54:46-52

32. Jenab E, Temelli F (2012) Density and volumetric expansion of carbon dioxide-expanded canola oil and its blend with fully-hydrogenated canola oil. J Supercrit Fluids 70:57-65

33. Wei W, Jinlong $\mathrm{G}$ (2010) Methanation of carbon dioxide: an overview. Front Chem Sci Eng 5:2-10

34. Ortega JV, Renehan AM, Liberatore MW, Herring AM (2011) Physical and chemical characteristics of aging pyrolysis oils produced from hardwood and softwood feedstocks. J Anal Appl Pyrolysis 91:190-198

35. Oasmaa A, Kuoppala E, Ardiyanti A, Venderbosch RH, Heeres HJ (2010) Characterization of hydrotreated fast pyrolysis liquids. Energy Fuels 24:5264-5272 